as Director of Naval Construction would be little short of writing a volume; and cannot be attempted here.

On rejoining the Admiralty in 1885 , Sir William at once set about making improvements and developments in all classes of designs so as to embody in them all the improvements continually being made in guns, armour, and propelling machinery. Limitations of space will not permit us to describe the various type of vessels which received considerable development under his hands, and mention can be made of one or two points only.

As regards battleships, he made a special study of all the elements which go to make for fighting efficiency, having regard to the rapidly changing concurrent general features of the engineering world, and in 1889 wrote a famous paper for the Institution of Naval Architects, giving quite frankly all his views of the subject, and stating the points that had decided the Board in ordering the then new ships the Empress of India and her sisters. He was much criticised by many members, but it was generally felt that his views were sound. In principle and in main features they were adopted, with such extension as arose from the general increase in size and cost of ships up to the introduction of the Dreadnought type of ship.

Sir William received many distinctions. He was honorary vice-president of the Institution of Naval Architects, and past president of the chief engineering societies and honorary member of many others. He was elected a Fellow of the Royal Society in I888, and was created K.C.B. in 1895 . At the time of his regretted death on Thursday last he was the president-elect of the British Association for the meeting to be held at Birmingham next September, and his loss to the association will be severely felt. His name will ever be remembered in the annals of the British Navy and the records of engineering science.

\section{PROF. ADAM SEDGWICK, F.R.S.}

THE late Prof. Sedgwick was grand-nephew of Adam Sedgwick, Woodwardian professor in the University of Cambridge from 18 I8 until 1873 , sometimes known as the "old Adam." Their ancestors had been "statesmen" in the Dale of Dent for several centuries. Adam Sedgwick, jun., was the son of Richard Sedgwick, vicar of Dent, and the affection he always bore towards his native valley was evidenced by the fact that he sent his second boy to the school at Sedbergh, at the mouth of the Dale.

Our Adam was born in I854 at Norwich, where his great-uncle held a canonry. He was educated at Marlborough College, and after a short time at King's College, London, he entered in 1874 Trinity College, Cambridge. At that time the recently established professorship of zoology and comparative anatomy was held by Prof. Newton, and Mr. J. W. Clark was superintendent of the Museum of Zoology. Prof. (afterwards Sir George) Humphrey was professor of anatomy, and
Michael Foster had recently come to Cambridge as prælector in physiology to Trinity College. A demonstrator in comparative anatomy had just been appointed by the University, and the late Prof. Bridge was the first to hold that office; a curatorship of the Strickland collection of birds was founded in the year that Adam Sedgwick came into residence, and $\mathrm{Mr}$. O. Salvin was the first Strickland curator. It has not always been recognised that Cambridge led the way in the practical teaching of zoology and biology. Three years before Adam Sedgwick came into residence, J. W. Clark had, with the aid of his friend Mr. Bridge, started laboratory work in these subjects. This class-work was carried on with renewed activity by Milnes-Marshall and by Frank Balfour, and by the time that Adam Sedgwick began to be interested in zoology and to be influenced, as he was for life, by Balfour, practical classes were in full working order, although conducted in adverse circumstances of space ard equipment.

Sedgwick was placed in the first class of the natural sciences tripos in the year 1877 . In the same list were the names of Prof. Bower, of Glasgow, Dr. Fenton, of Christ's, and Dr. Alex. Hill, of Downing. Compared with the modern days, the tripos was insignificant in numbers, but modern days may not find it easy to equal the quality of this list. After taking his degree Sedgwick definitely cast in his lot with zoology. In I 880 the zoology class conducted by Balfour, with Sedgwick as assistant, was held in the room now occupied by physiological chemistry, at the top of Fawcett's building overlooking Corn Exchange Street.

The University was so conscious of Balfour's ability that, in $\mathbf{1} 882$, he was appointed professor of animal morphology, it being understood that the professorship would lapse with his death, and that it carried but a small emolument with it. The tragedy in the Alps the same year brought this professorship to an end, and Sedgwick was left in a peculiarly difficult position. He had but recently taken his master's degree, he was but little older than some of the senior students, and the management of a comparatively large and rapidly growing department devolved on him.

Before the beginning of the October term of the same year Prof. Newton, Michael Foster, Prof. Humphrey, and J. W. Clark addressed a letter to the Vice-Chancellor, urging that the work which Balfour had so wonderfully begun should be carried on, and that the general supervision of the class should be entrusted to Sedgwick, who had been Balfour's demonstrator for some years, and had been in charge of the class during the Lent and May terms, when Balfour had been either ill or away. This was arranged, and Sedgwick was happy in securing the assistance of Mr. IV. Heape, of Trinity College, and Mr. W. R. F. Welldon, of St. John's, as demonstrators, and c little later on of $\mathrm{Mr}$. W. H. Caldwell, of Caius, who was then, with the aid of Mr. Threlfall, of the same college, at work on their automatic microtome.

The University was anxious to assist Sedgwick NO. 2262 , VOL. 9I] 
in every way in carrying on his difficult task. At the time of Balfour's death it was already building a spacious laboratory and private rooms adjoining it to accommodate students of zoology. Owing to the rearrangement of the M.B. examination, further increase soon became necessary, and this the University provided in 1884 by bodily lifting the roof off the Mineralogical Museum and building up walls under it.

Whilst Prof. Newton kept alive in the University the study of zoology as a study of living animals, Sedgwick promoted the interest of those more interested in the architecture or morphology of the animal body. He had become in I880 a Fellow, and soon after lecturer at Trinity College, and the college (as is the habit of Cambridge colleges) allowed his University lectures to count as though they were delivered to, as they were paid for by, the college.

Sedgwick's first researches, as was natural, were on embryology, and were mainly concerned with the origin of the vertebrate kidney. He also published a short paper on Chiton, with two useful diagrams, but the work by which he will be longest remembered was his investigation into the embryology and anatomy of the Cape species of Peripatus. His investigations did much to clear up the nature of the body-cavity of the Arthropods, and to explain what had become of the colom in the members of this group. What he found in the developing egg of Peripatus started him on more than one interesting speculation. His views on the cell-theory, at one time much criticised, have largely come into their own. Another of his ingenious hypotheses largely based on the same research related to the origin of segmentation in metameric animals. At one time he had contemplated a final volume to his "Zoology," which was to deal with the theory and philosophy of the science, and it is very greatly to be regretted that this has not appeared. His originality of outlook and power of expression would have made it a valuable contribution to the more speculative side of zoology.

As a result of his work on Peripatus, he was elected a Fellow of the Royal Society in I886, and he twice served on the council of that body. In 1897 he became tutor at Trinity College, and for ten years held that position. Although he continued with his usual vigour the teaching and management of a great department, this appointment practically coincided with his ceasing research. It also coincided with the production of what is undoubtedly the most comprehensive textbook in English written, with the exception of one or two groups, by one man. Sedgwick's aim in his great text-book was to mention practically every genus. Of course, in some groups, such as the insects, this ambition could not be realised; but his broad outlook, his wide knowledge, and, on certain lines, his philosophical insight have made the book invaluable to all advanced students of the subject. It will be, with his work on Peripatus, a lasting memorial to his name.

In 1907 Prof. Newton died, and the chair of zoology then passed to Adam Sedgwick, who for NO. 2262 , VOL. 9I] so many years had been the head of the department of morphology. To the great regret of his Cambridge friends he only held it for two years. In 1909 he accepted the post of professor of zoology at the Imperial College of Science and Technology, and for the last three and a half years he spent his whole energies in the attempt to build up a school of zoology in South Kensington.

For some months his friends had marked with dismay a serious decline in his health, but his sudden death on February 27 came as a shock to many who read of it in their morning paper last Friday.

If one may say a few words about his personality, he was extraordinarily "alive," very trenchant in his criticisms, not a good lecturer, the reverse of fluent, yet by his earnestness and by the vigour of his language arresting attention. Still he was a successful teacher. The best course he gave was that on embryology; here he was giving his class the results of first-hand, personal knowledge, and his students felt they were listening to a master of the subject. His very entrance into the great laboratory where some hundred students were being taught by eight or ten demonstrators put a new spirit into the thing. The atmosphere, as it were, became electrified, and teachers and taught were "keyed up." As a conversationalist he was most interesting, holding often bizarre and impossible views, and maintaining them with extraordinary energy and humour. If one may judge by portraits and statues, he was in physique very like his great-uncle--small and frail in body, his face was quick and keen. Like his great-uncle again, he was an eager and rapid worker, one who never spared himself when working at the subject to which he devoted his life.

\section{NOTES.}

THE following fifteen candidates have been selected bv the council of the Royal Society to be recommended for election into the society :-Prof. V. H. Blackman, professor of plant physiology and pathology at the Imperial College of Science and Technology; Dr. William Bulloch, professor of bacteriology in the University of London; Mr. D. L. Chapman, fellow and tutor of Jesus College, Oxford; Prof. W. E. Dalby, professor of civil and mechanical engineering at the Imperial College of Science and Technology; Dr. T. R. Elliott, lecturer in practical medicine at University College Hospital Medical School; Prof. J. C. Fields, professor of mathematics in Toronto University; Dr. J. S. Flett, assistant director of the Geological Survey of Scotland; Prof. J. P. Hill, Jodrell professor of zoology and comparative anatnmy at University College, London; Mr. A. R. Hinks, chief assistant at the Cambridge University Observatory; Prof. F. Keeble, professor of botany in University College, Reading; Prof. A. Keith, Hunterian professor of the Royal College of Surgeons; Dr. K. Lucas, lecturer in natural sciences, Trinity College, Cambridge; Prof. O. W. Richardson, professor of physics in Princeton University; Dr. W. Rosenhain, superintendent of the metallurgical department of the 